\title{
Mineralogical analysis of Brazilian ceramic sedimentary clays used in red ceramic
}

\section{(Análise mineralógica de argilas sedimentares brasileiras usadas em cerâmica vermelha)}

\author{
G. P. Souza, S. J. G. Sousa, L. A. H. Terrones, J. N. F. Holanda \\ Group of Ceramic Materials - LAMAV, Northern Fluminense State University \\ Av. Alberto Lamego, 2000, Campos dos Goytacazes, RJ, Brasil 28013-602 \\ holanda@uenf.br
}

\begin{abstract}
The present work focuses on the mineralogical analysis of sedimentary clay material samples collected from deposits located in the Campos dos Goytacazes-RJ (Brazil) region. These samples are representative and widely used by the ceramic plants in production of bricks and roofing tiles. The samples were selected with the objective of analyzing their characteristics regarding chemical composition, loss on ignition, X-ray diffraction, morphology, particle size, plasticity and thermal analysis. The sedimentary red clays have low amount of $\mathrm{SiO}_{2}$, high amount of $\mathrm{Al}_{2} \mathrm{O}_{3}$, and high loss on ignition. In addition, it was found that the character of the clays is typically kaolinitic.
\end{abstract}

Keywords: sedimentary clays, mineralogy, industrial minerals.

\section{Resumo}

O presente trabalho é focado sobre a análise mineralógica de amostras de argilas sedimentares coletadas de depósitos localizados na região de Campos dos Goytacazes-RJ (Brasil). Estas amostras são representativas e largamente usadas na produção de blocos cerâmicos e telhas. As amostras foram selecionadas com o intuito de analisar suas características com respeito à composição química, perda ao fogo, difração de raios X, morfologia, análise de tamanho de partícula, plasticidade e análise térmica. As argilas vermelhas sedimentares têm baixa quantidade de $\mathrm{SiO}_{2}$, alta quantidade de $\mathrm{Al}_{2} \mathrm{O}_{3}$ e alta perda ao fogo. Além disso, foi determinado que o caráter das argilas é tipicamente caulinítico.

Palavras-chave: argilas sedimentares, mineralogia, minerais industriais.

\section{INTRODUCTION}

Clays are raw materials abundantly found, and widely used by the ancient civilizations to make figures and ceramic artifacts $[1,2]$. Nowadays, they are still used in the manufacture of ceramic products such as bricks, roofing tiles, porcelain, sanitary wares, wall tiles and floor tiles, and also are used in different industrial chemical processes.

Clays are polymineralic fine-grained inorganic materials $(<2 \mu \mathrm{m})$, being constituted essentially of clay minerals and nonclay materials as impurities. Clays are seldom pure. Each of these constituents contributes to the plastic forming and fired characteristics of the ceramic bodies. The clay minerals are hydrated aluminosilicates with layer structures that are responsible for the characteristic properties of the clays. There are a variety of clay minerals, including kaolinite, halloysite, illite, montmorillonite, clorite, among others [3, 4].

There are many areas near the right riverside of the Paraíba do Sul river in Campos dos Goytacazes (RJ,
Brazil) region that contain quaternary sedimentary clay deposits. These deposits have thickness between 1.5 to $4.5 \mathrm{~m}$, and are widely used as raw materials in the red ceramic industry [5]. The local ceramic industry, which assembles about 110 plants, is mainly based on the manufacturing of bricks, roofing tiles and ceramic blocks. These ceramic products are usually obtained by empirical blends of the clays. The net annual mean production of Campos dos Goytacazes ceramic industry is around 2,000,000 tons. In general, the quality of the red ceramic products is often poor. In particular there is a lack of more knowledge on the composition of the sedimentary red clays. Thus, the knowledgement of the composition of these clays has both academic value and immediate commercial interest.

In this paper the chemical and mineralogical composition of representative sedimentary clay samples from Campos dos Goytacazes-RJ (Brazil) region were examined. A wide range of techniques was employed, including X-ray diffraction (XRD), differential thermal analysis (DTA), thermogravimetry (TGA), dilatometry, 
scanning electron microscopy (SEM), transmission electron microscopy (TEM), and X-ray fluorescence.

\section{EXPERIMENTAL}

\section{Materials}

In this work three sedimentary clay samples collected from different deposits were used. These clays are considered representative of the main types of raw clay materials commonly used by the red ceramic industry from the Campos dos Goytacazes region. The samples were labeled F1, F2 and F3, respectively. The samples were dried and sieved to pass a 40 mesh $(<425 \mu \mathrm{m})$ sieve.

\section{Methods}

X-ray diffraction analysis was performed (URD-65 Diffractometer, Seifert) using monochromatic $\mathrm{Cu}-\mathrm{k} \alpha$ radiation at $40 \mathrm{kV}$ and $40 \mathrm{~mA}$ over non-oriented specimens. Scanning speed was $1.5^{\circ}(2 \theta) / \mathrm{min}$. The phases were identified from peak positions and intensities using reference data from the JCPDS handbook.

Chemical analysis of the clay powders was determined by X-ray fluorescence. The loss on ignition (LOI) was determined according to $\mathrm{LOI}=\left(\mathrm{W}_{\mathrm{d}}-\mathrm{W}_{\mathrm{f}}\right) / \mathrm{W}_{\mathrm{d}} \times 100$, where $\mathrm{W}_{\mathrm{d}}$ is the weight of the dry sample at $110^{\circ} \mathrm{C}$, and $\mathrm{W}_{\mathrm{f}}$ is the weight of the calcined sample at $1100^{\circ} \mathrm{C}$ during $1 \mathrm{~h}$.

Particle size analysis of the samples was determined by the combination of sieving and sedimentation procedures according to the NBR 7181-84 [6]. The plasticity of the clays was determined according to the NBR 6459-84 [7] and NBR 7180-84 [8] procedures.

The morphology and texture of the clay particles were determined by scanning electron microscopy, using a Zeiss DSM 962 SEM coupled with EDS (energy dispersive spectroscopy). A Zeiss Omega 912 TEM operating at a 80 $\mathrm{kV}$ acceleration voltage was also used to morphological identification of clay particles.

TGA/DTG/DTAwere carried out on the as-received samples (SDT - 2960 Simultaneous TGA-DTA, TA Instruments) under air atmosphere from room temperature up to $1150{ }^{\circ} \mathrm{C}$ at a heating rate of $10^{\circ} \mathrm{C} / \mathrm{min}$. Dilatometric analysis of rectangular samples $\left(35.7 \times 7 \times 7 \mathrm{~mm}^{3}\right)$ were taken within the 5 to $1000{ }^{\circ} \mathrm{C}$ range using a heating rate of $5{ }^{\circ} \mathrm{C} / \mathrm{min}$ under air atmosphere (RB-115 Dilatometer, BP Engenharia).

\section{RESULTS AND DISCUSSION}

$\mathrm{X}$-ray diffraction of the clay samples is shown in Fig. 1. The sedimentary clays have similar mineralogical composition. The following mineralogical phases were found: kaolinite $\left(\mathrm{Al}_{2} \mathrm{O}_{3} \cdot 2 \mathrm{SiO}_{2} \cdot 2 \mathrm{H}_{2} \mathrm{O}\right)$, quartz $\left(\mathrm{SiO}_{2}\right)$, and gibbsite $\left(\mathrm{Al}_{2}(\mathrm{OH})_{6}\right)$. The kaolinite is the majority phase in all clay samples. Kaolinite is a two-layer 1:1 silicate, and is the

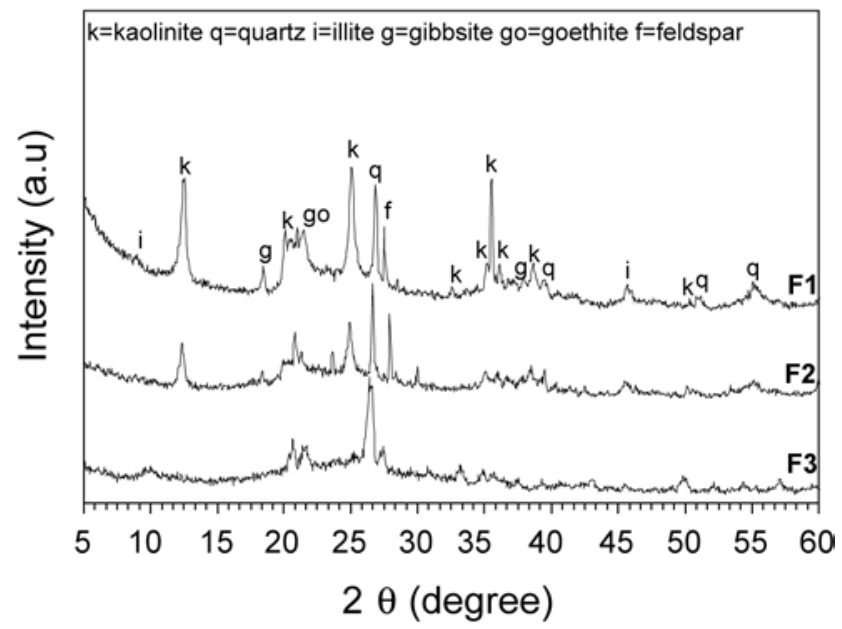

Figure 1: X-ray diffraction patterns of the sedimentary clays. [Figura 1: Difratogramas de raios $X$ das argilas sedimentares.]

principal specimen of its group [4]. It is structurally formed by one layer of silica tetrahedral $\left(\mathrm{SiO}_{4}\right)$, and one layer of octahedral gibbsite, neither bearing cations nor $\mathrm{H}_{2} \mathrm{O}$ molecules between the structural layers. Illite has been identified and is a minor phase in the clay samples from the Campos dos Goytacazes region. Goethite $\left(\alpha-\mathrm{Fe}_{2} \mathrm{O}_{3} \cdot \mathrm{H}_{2} \mathrm{O}\right)$ and potassium feldspar also have been identified by its weaker diffraction lines.

The chemical compositions of the sedimentary clays are shown in Table I. In this table the $\mathrm{SiO}_{2} / \mathrm{Al}_{2} \mathrm{O}_{3}$ ratio is also shown. All the clays present low amount of $\mathrm{SiO}_{2}$ and high amount of $\mathrm{Al}_{2} \mathrm{O}_{3}$, whose $\mathrm{SiO}_{2} / \mathrm{Al}_{2} \mathrm{O}_{3}$ ratio varied between 1.36 and 1.66. This indicates that the studied clays have high amount of clay minerals, mainly kaolinite according to the results of X-ray diffraction (Fig. 1). The loss on ignition (LOI) of the clays is relatively high, and close to the theoretical value of kaolinite $(13.95 \%)$. The loss on ignition

Table I - Chemical composition of the clay samples (wt.\%). [Tabela I - Composição química das amostras de argilas (\% em peso).]

\begin{tabular}{|c|c|c|c|}
\hline \multirow[b]{2}{*}{ Compounds } & \multicolumn{3}{|c|}{ Sedimentary clay samples } \\
\hline & F1 & $\mathrm{F} 2$ & F3 \\
\hline $\mathrm{SiO}_{2}$ & 46.42 & 43.21 & 43.53 \\
\hline $\mathrm{Al}_{2} \mathrm{O}_{3}^{2}$ & 27.90 & 29.21 & 31.60 \\
\hline $\mathrm{Fe}_{2} \mathrm{O}_{3}^{3}$ & 9.10 & 9.38 & 8.64 \\
\hline $\mathrm{TiO}_{2}^{3}$ & 1.32 & 1.47 & 1.29 \\
\hline $\mathrm{MnO}^{2}$ & 0.11 & 0.06 & 0.05 \\
\hline $\mathrm{MgO}$ & 0.71 & 1.13 & 0.75 \\
\hline $\mathrm{CaO}$ & 0.22 & 0.24 & 0.13 \\
\hline $\mathrm{K}_{2} \mathrm{O}$ & 1.67 & 1.45 & 1.26 \\
\hline $\mathrm{Na}_{2} \mathrm{O}$ & 0.36 & 0.53 & 0.32 \\
\hline LOI & 11.96 & 12.72 & 12.47 \\
\hline $\mathrm{SiO}_{2} / \mathrm{Al}_{2} \mathrm{O}_{3}$ & 1.66 & 1.45 & 1.36 \\
\hline
\end{tabular}

$L O I=$ loss on ignition. 


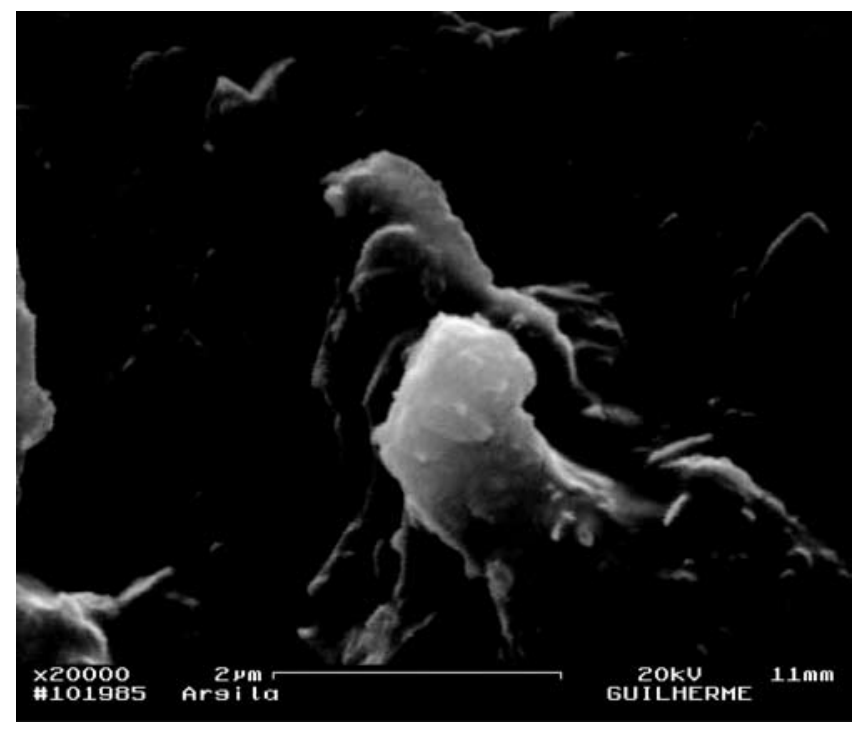

Figure 2: Morphology of the clay particles.

[Figura 2: Morfologia das partículas de argila.]

is associated with the presence of clay minerals, hydroxides, and organic matter. The amount of alkaline oxides $\left(\mathrm{K}_{2} \mathrm{O}\right.$ and $\mathrm{Na}_{2} \mathrm{O}$ ) that act as flux materials is low. In clay-based bodies, flux materials enable to lower the temperature of which liquid or glass forms during firing. This glass, when cooled, binds the grains of the body together. The amount of earth-alkaline oxides $(\mathrm{CaO}$ and $\mathrm{MgO})$ that are auxiliary fluxes also is low, indicating that the studied sedimentary clays are non-carbonatic. The results also show a large amount of Fe oxide that can be present in form of goethite or colloidal particles. Additionally, $\mathrm{Fe}^{3+}$ cations can partially substitute the $\mathrm{Al}^{3+}$ cations in the octahedral sites of the kaolinite structure $[9,10]$. This oxide gives the reddish color of the clay-based products after firing.

Morphological aspects of a clay powder sample obtained

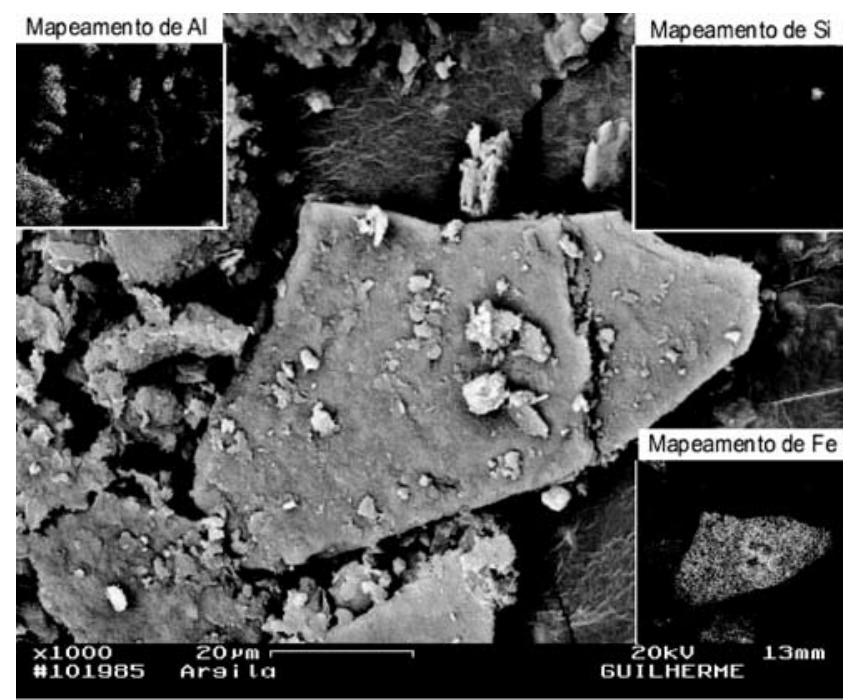

Figure 3: Mapping of a clay particle by EDS.

[Figure 3: Mapeamento de uma partícula de argila por EDS.] by SEM are shown in Fig. 2. Kaolinite plates with size below $2 \mu \mathrm{m}$, leading to pile up to agglomerates were observed. In Fig. 3 a plate of $\mathrm{Al}, \mathrm{Si}$ and $\mathrm{Fe}$ rich mineral is shown. It is worth noting that the Campos dos Goytacazes clays are Fe rich (Table I), making this element to take part of the aluminosilicate ordinary structure.

Fig. 4 shows a micrograph obtained by TEM. Kaolinite hexagonal platelets can be cleary observed. The plates are up to $2 \mu \mathrm{m}$ large. In addition, it was also observed a small amount of tubular particles typical of halloysite. These results obtained by TEM are very interesting, because halloysite usually is not detected by other characterization techniques. In the case of the $\mathrm{X}$-ray diffraction, the halloysite main peak is overlapped with the peak of kaolinite [11]. Sometimes halloysite is also not detected if is present in a small amount.

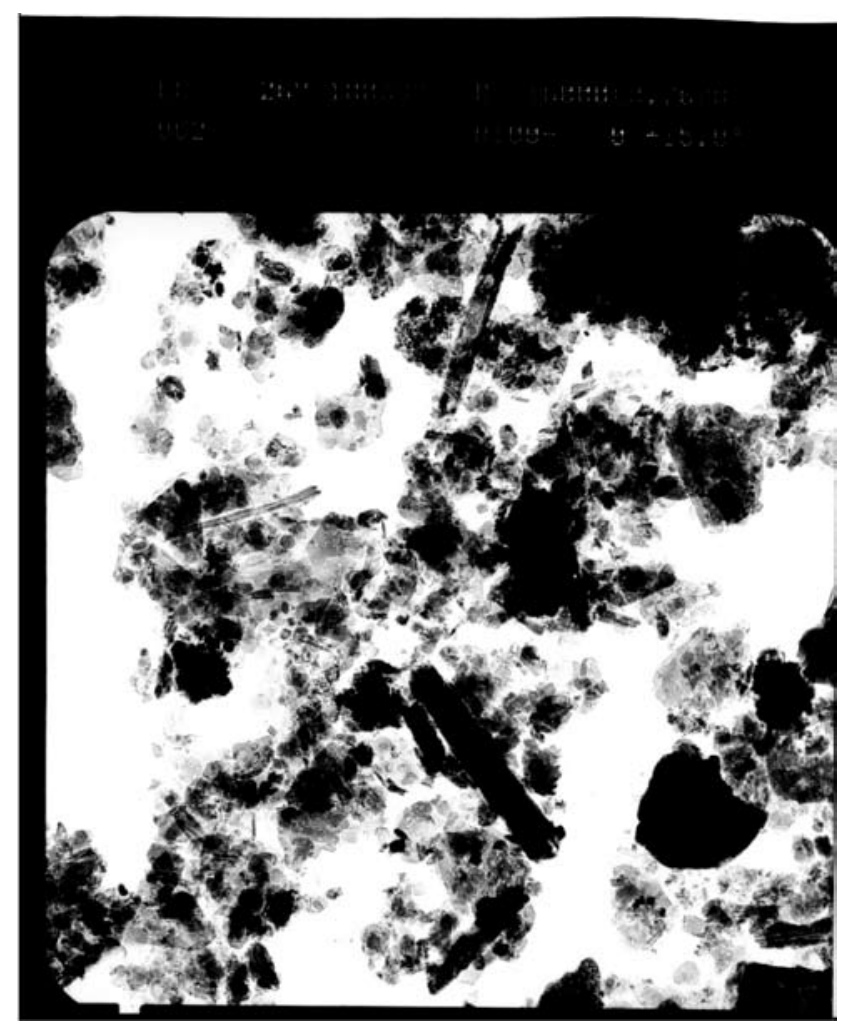

Figure 4: TEM micrograph of clay powder.

[Figura 4: Micrografia de pó de argila obtida por MET.]

Fig. 5 shows the results of particle size analysis of the clay samples. It can be observed that the clay fraction $(<2 \mu \mathrm{m})$ varies from 37 to $58 \%$, followed by silt $(2 \leq \mathrm{x}<60 \mu \mathrm{m})$ of 34 to $47 \%$, and sand $(60 \leq x<600 \mu \mathrm{m}) \quad$ from 7 to $18 \%$. These results are in agreement with the literature $[5,12]$, where the red clays from Campos dos Goytacazes-RJ region present large variability in terms of particle size, depending of the deposit used. As a consequence, it is expected also a variation in the plasticity of these clays (Fig. 6). The more is the amount of clay minerals, the greater the plasticity is observed. The studied clays are formed mainly by the kaolinite clay mineral. 


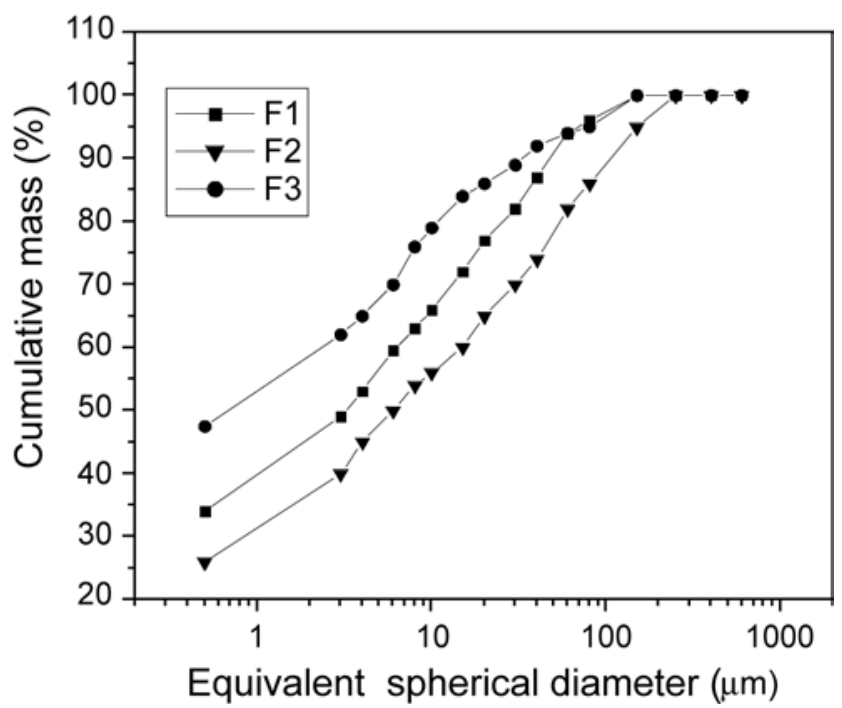

Figure 5: Particle size distribution for the studied clays.

[Figura 5: Distribuição de tamanho de partículas das argilas.]

Typical TG/DTG/DTA curves of the clay samples are shown in Figs. 7 and 8, respectively. It is noted that the thermal behavior of the sedimentary clays is coherent with their chemical and mineralogical composition. Three weight loss events are seen in the TG and DTG curves at $54.10-56.56{ }^{\circ} \mathrm{C}$,

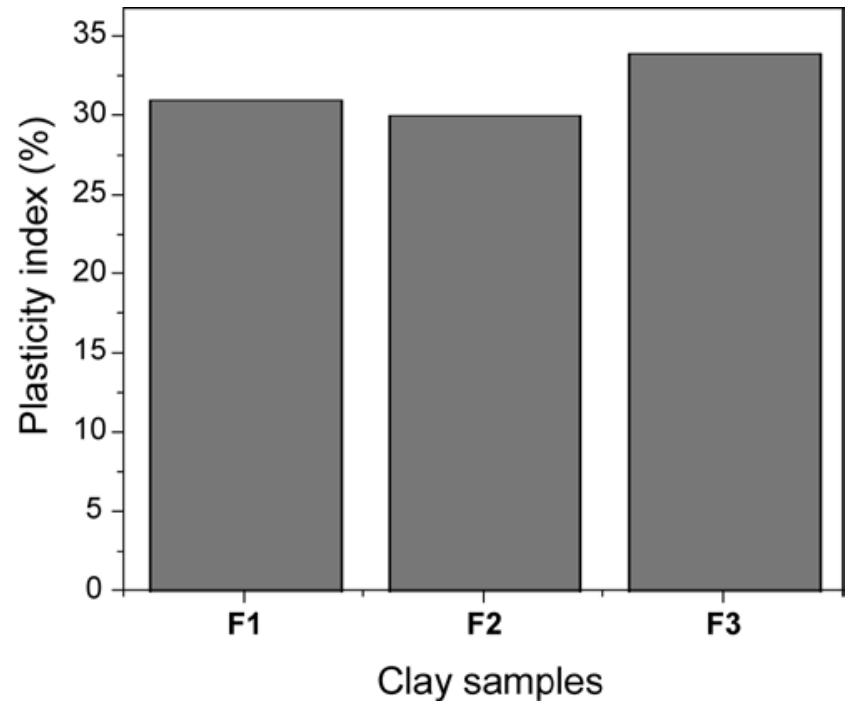

Figure 6: Plasticity of the clay samples.

[Figura 6: Plasticidade das amostras de argilas.]

$259.10-264.31^{\circ} \mathrm{C}$ and $492.50-493.00^{\circ} \mathrm{C}$, whose total weight loss is in the $11.59-12.60 \%$ range. According to the DTA curves shown in Figs. 7 and 8, the first endothermic peak is related to the evolution of the physically adsorbed water by the kaolinite particles. The second weight loss occurs due

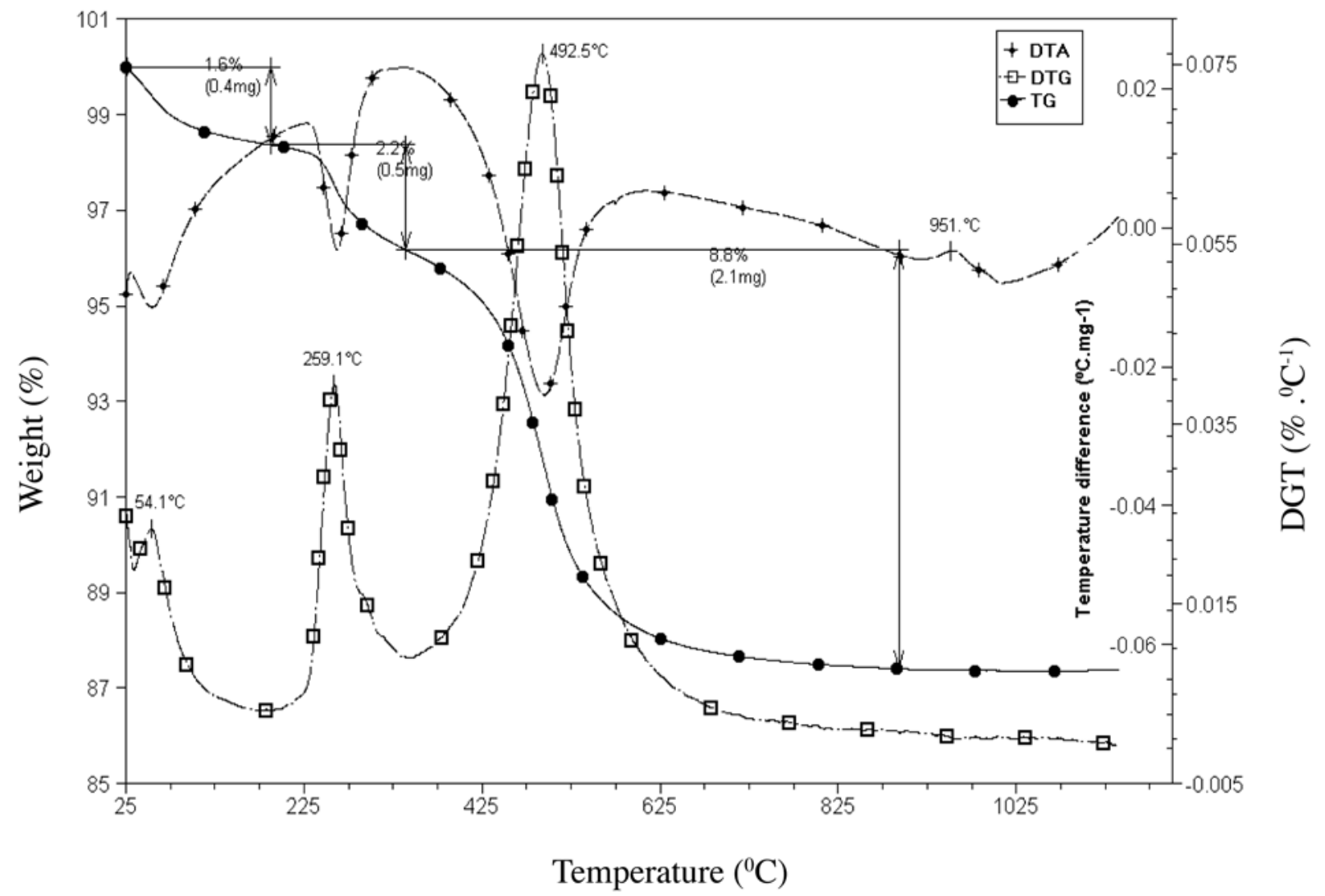

Figure 7: TG/TGD/DTA curves of the clay sample F1.

[Figura 7: Curvas ATG/DTG/ATD da amostra de argila F1.] 


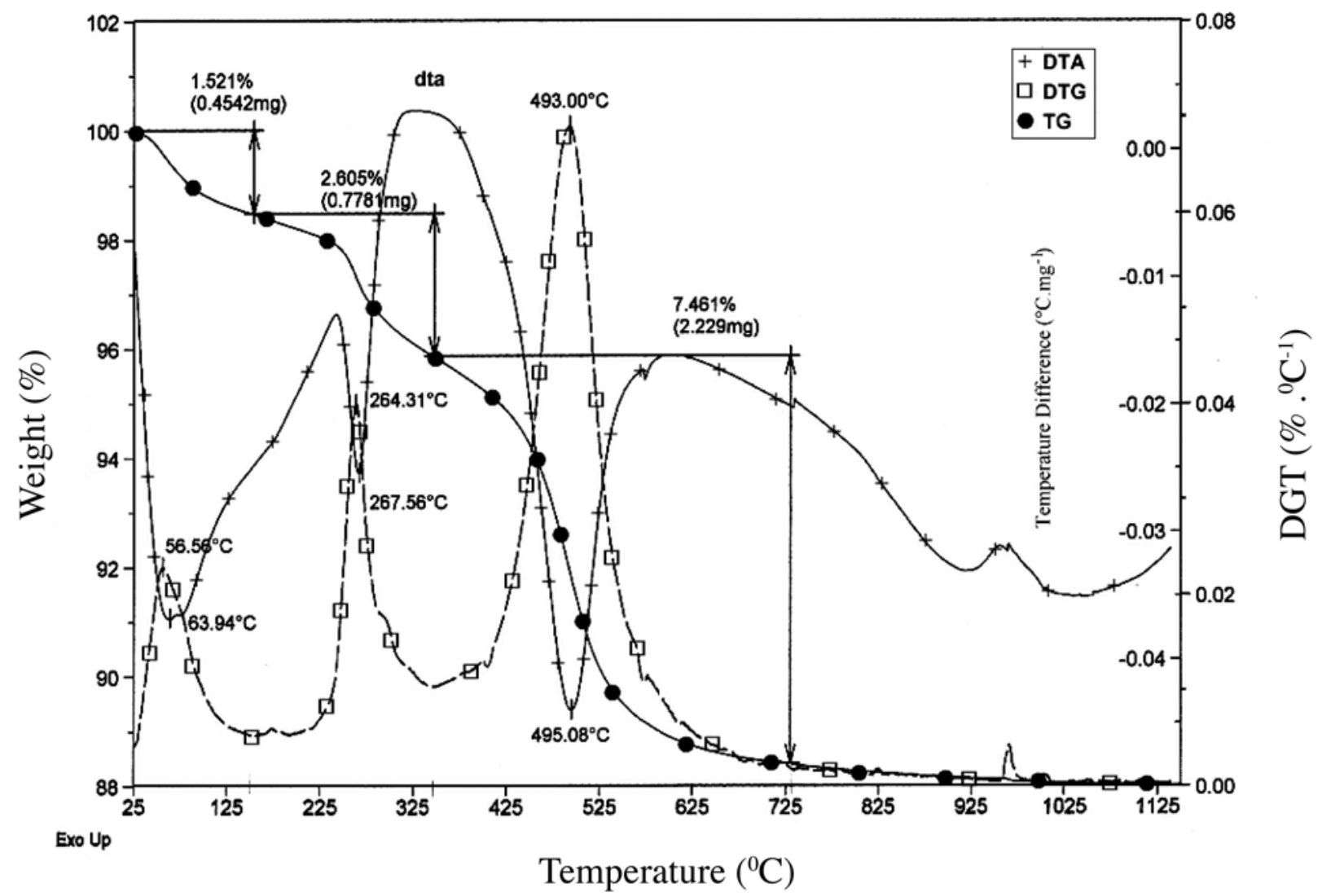

Figure 8: TG/TGD/DTA curves of the clay sample F2.

[Figura 8: Curvas ATG/DTG/ATD da amostra de argila F2.]

to the evolution of water resulting from the dehydration of gibbsite and its subsequent transformation into a transition alumina phase. The third weight loss is associated mainly to dehydroxylation of kaolinite, which transforms into metakaolinite. The endothermic event related to $\alpha-\beta$ quartz inversion should have been probably overlapped.

A large exothermic peak around $325^{\circ} \mathrm{C}$ due the organic matter decomposition was observed for all studied samples. In addition, an exothermic event within the 951 - $960{ }^{\circ} \mathrm{C}$ range was observed. This thermal event can be related to transformation of the metakaolinite to a spinel structure or a Si-containing $\gamma-\mathrm{Al}_{2} \mathrm{O}_{3}$ and amorphous silica [13]. In addition, it is also possible primary mullite be formed [14].

The clay fraction $(<2 \mu \mathrm{m})$ and gibbsite amounts can be estimated from the TG measurements. In this case the weight loss within the temperature range of 200 to $300^{\circ} \mathrm{C}$ is considered to be due to the dehydration of gibbsite, whereas that within the 400 to $600{ }^{\circ} \mathrm{C}$ range is due to the dehydroxylation of clay components $[15,16]$. The clay minerals of the studied samples are a mixture of kaolinite, halloysite and illite with great predominance of kaolinite. However, for calculation effect it was only considered kaolinite. The kaolinite and gibbsite amounts are given in Table II. High relative amounts of kaolinite (53.5 to $71.7 \%$ ) and gibbsite (5.8 to $7.5 \%$ ) were observed. These results confirm the predominance of the kaolinite clay mineral in the studied samples, and are consistent with X-ray diffraction and TEM results. In addition, it is likely that $\mathrm{Al}_{2} \mathrm{O}_{3}$ (Table I) does not occur in its free form in the samples, being bonded to the clay minerals and gibbsite structures.

The dilatometric curve of the sedimentary clay (sample F3) is shown in Fig. 9. The clay sample exhibits a dilatometric behavior typical of kaolinitic clay [3], corroborating the mineralogy and chemical composition of the clay. Initially a small expansion up to $550^{\circ} \mathrm{C}$ is noted, followed by three regions of active shrinkage at $550{ }^{\circ} \mathrm{C}-700{ }^{\circ} \mathrm{C}, 700{ }^{\circ} \mathrm{C}$ $900{ }^{\circ} \mathrm{C}$ and $900{ }^{\circ} \mathrm{C}-1000{ }^{\circ} \mathrm{C}$, respectively. The first shrinkage within the $550{ }^{\circ} \mathrm{C}-700{ }^{\circ} \mathrm{C}$ range may be due to metakaolinite formation, where a great loss of chemically bound water occurred. The second shrinkage between $700{ }^{\circ} \mathrm{C}-900{ }^{\circ} \mathrm{C}$ is less harsh, and can be attributed to particles sintering. In this temperature region the sintering is dominated by particleto-particle contact mainly of metakaolinite. In addition, solid state sintering, likely by surface diffusion [17], is the dominant mechanism. The third shrinkage within the $900{ }^{\circ} \mathrm{C}-1000{ }^{\circ} \mathrm{C}$ range seems to be due the recrystallization of new ceramic phases, and mainly the onset of vitrification. In this temperature range a considerable shrinkage of the clay occurred. 
Table II - Amounts of kaolinite and gibbsite (\%).

[Tabela II - Quantidades de caulinita e gibsita (\%).]

\begin{tabular}{ccc}
\hline Samples & Kaolinite & Gibbsite \\
\hline F1 & 63.1 & 6.4 \\
F2 & 53.5 & 7.5 \\
F3 & 71.7 & 5.8 \\
\hline
\end{tabular}

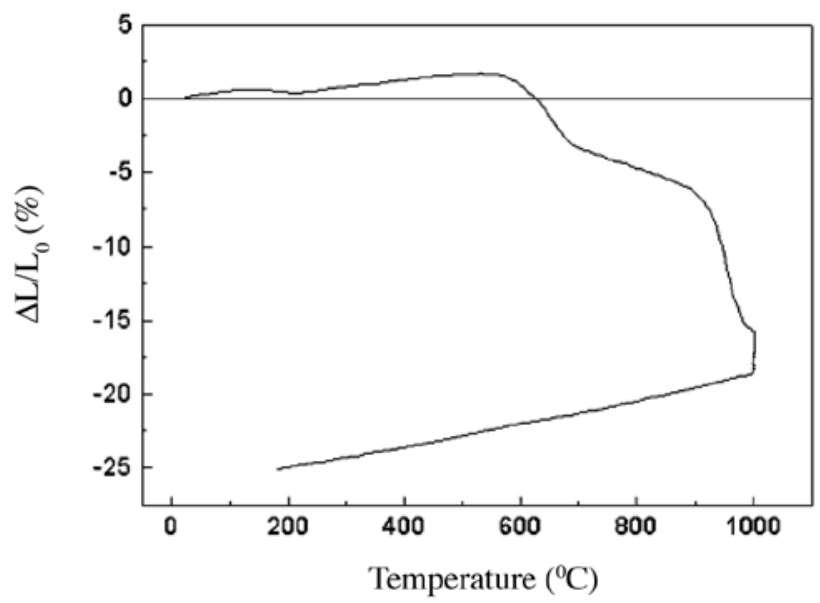

Figure 9: Dilatometric curve of the clay sample F3.

[Figura 9: Curva dilatométrica da amostra de argila F3.]

\section{CONCLUSIONS}

In this work sedimentary clays from Brazil used in fabrication of red ceramic were investigated. The mineralogical studies indicated that the clays have kaolinite as the main mineral phase, and illite, quartz, and gibbsite as impurities. TEM analysis also indicated the presence of a small amount of tubular halloysite. In general, the clay samples are also chemically very similar. Although the analyzed clays have various minerals, the TG/ DTG/DTA and dilatometric curves suggest that the character of these clays is predominantly kaolinitic.

\section{ACKNOWLEDGEMENTS}

This work was partially financed by CNPq and CAPES, whose support is gratefully acknowledged. The authors also would like to thank Dr. Rubén Sánchez for the support in TG/DTG/DTA analyses.

\section{REFERENCES}

[1] F. H. Norton, Elements of Ceramics, $2^{\text {nd }}$ Ed., AddisonWesley, N. York (1974).

[2] R. A. Haber, P.A. Smith, Overview of traditional ceramics, in Engineered Materials Handbook, ASM International, Vol. 4 (1991) 3-15.

[3] C. F. Gomes, Argilas - o que são e para que servem, Fundação Calouste Gulbenkian, Lisboa (1988) 457p.

[4] P. S. Santos, Ciência e Tecnologia de Argilas, $2^{\mathrm{a}}$ Ed., Ed. Edgar Blücher, Vol. 1, S. Paulo (1989) 45-71.

[5] J. N. F. Holanda, C. M. F. Vieira, Mundo Cerâmico 82 (2002) 29-31.

[6] ABNT, NBR 7181-84, Solo: Análise Granulométrica (1984).

[7] ABNT, 6459-84, Solo: Determinação do Limite de Liquidez (1984).

[8] ABNT, 7180-84, Solo: Determinação do Limite de Plasticidade (1984).

[9] R. S. T. Manhães, L. T. Auler, M. S. Sthel, M. S. O. Massunaga, J. G. Carrió, D. R. Santos, E. C. Silva, A. GarciaQueiroz, H. Vargas, Appl. Clay Sci. 21 (2002) 303-311.

[10] Y. Hu, X. Liu, Minerals Eng. 16 (2003) 1279-1284.

[11] G. W. Brindley, P. S. Santos, H. S. Santos, The Am. Mineral. 48 (1963).

[12] J. Alexandre, Tese de Doutorado, UENF-PPGCE, Campos dos Goytacazes, RJ (2000).

[13] C. Y. Chen, G. S. Lan, W. H. Tuan, Ceram. Int. 26 (2000) 715-720.

[14] G. W. Brindley, Cerâmica 24, 102 (1978) 217-224.

[15] A. M. El-Shabiny, S. M. Hammad, I. A. Ibrahim, A. K. Ismail, J. Thermal Anal. 46 (1996) 1434.

[16] N. Fava, M. G. Torres, S. L. R. Lenharo, E. S. Martins, G. R. Boaventura, J. C. Gaspar, Anais do $5^{\circ}$ Cong. Bras. Cimento, S. Paulo, SP (1999) 4.

[17] W. D. Kingery, M. Berg, J. Appl. Phys. 26, 10 (1955) 1205-1212.

(Rec. 22/02/2005, Rev. 08/08/2005, Ac. 04/10/2005) 